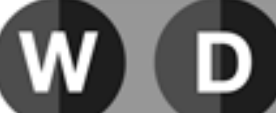

William Davidson Institute

AT THE UNIVERSITY OF MICHIGAN

\title{
Testing the causality between electricity consumption, energy use and education in Africa
}

By: Oussama BEN ABDELKARIM, Adel BEN YOUSSEF,
Hatem M'HENNI and Christophe RAULT

William Davidson Institute Working Paper Number 1084

September 2014 


\title{
Testing the causality between electricity consumption, energy use and education in Africa
}

\section{Oussama BEN ABDELKARIM}

African Development Bank

o.benadbdelkarim@afdb.org

\section{Adel BEN YOUSSEF}

GREDEG-CNRS \& Université de Nice Sophia-Antipolis adel.ben-youssef@unice.fr

\section{Hatem M'HENNI}

ESC Tunis, University of Manouba hatem.mhenni@topnet.tn

\section{Christophe RAULT ${ }^{*}$}

LEO (UMR CNRS 7322), University of Orléans (France); IZA,and CESifo ( Germany) ; and William Davidson Institute at the University of Michigan, Ann Arbor, Michigan (United States)

chrault@hotmail.com

\begin{abstract}
We investigate the existence of causal relationships between energy consumption and education (enrollment in primary secondary and higher education) for a sample of 16 African countries over the period 1971-2010 (according to availability of countries' data). We use the panel-data approach of Kónya (2006), which is based on SUR systems and Wald tests with country specific bootstrap critical values. Our results show that education and energy use are strongly linked in Africa. There is bidirectional causality between primary, secondary and higher education and energy use for several countries. Moreover, electricity consumption plays a crucial role in the energy-education links in Africa.
\end{abstract}

JEL Classification: Q43, Q53, Q56.

Keywords: Education, Energy use, Electricity consumption, Education for All, VAR.

${ }^{*}$ Corresponding author, University of Orléans, Rue de Blois-B.P.6739, 45067 Orléans Cedex 2, France. Website: http://chrault3.free.fr. 


\section{Introduction}

Education is fundamental for Africa's future development. As Africa is projected to double its population by 2050 (UN-Habitat 2014, Bloom et al. 2014b), its education sector faces major quantitative and qualitative challenges in primary, secondary and higher education. Most African countries need huge investments and capacity building in order to improve their education systems. Current African education trends show that these countries perform badly in all education sectors (Soucat and Ncube, 2014; AfDB, 2014).

African Countries are targeting Education for All and universal primary education is supposed to be reached by 2015 as one key Millennium Development goals (MDGs). But as 2015 is approaching there is no doubt that most African countries will not reach such target (Unesco, 2012). Structural limitations and lack of means does not allow reaching such target. Although access to primary school has risen to nearly $100 \%$, the rate of retention to the end of the primary cycle is much lower. Primary school dropout rates are high. In 42 African countries about 24.2 million primary-school-age children-53\% of them female-were not in school in 2010 (Bongjoh et al. 2014).

For secondary education, upper secondary schools GERs vary from less than $10 \%$ (Burkina Faso, Central African Republic and Niger) to more than 90\% (Mauritius, Seychelles and South Africa). Higher education GERs vary from less than 2\% (Eritrea, Malawi and Niger) to more than 30\% (Algeria, Egypt and Tunisia). African countries involved in international tests like the PISA (Tunisia and Mauritius) were ranked among the $10 \%$ worst scores (OCDE, 2011). Test in Reading and Mathematical show strong deficiencies of the education system in basic skills (Hungi and Thuku, 2010).

The Tertiary education system is far behind the ones in other regions in the world. Only 4 African universities belong to the Top 500 ANRW ranking of Jao Tang University of Shanghai, and no African university is ranked in the top 300. The best ranked universities in South Africa. Moreover, while enrolments in Africa grew from less than 200,000 in 1970 to an estimated 10 million today (Hayward and Ncayiyana, 2014), most of African universities are lacking teachers, means and basic commodities in order to challenge these new students' cohorts (Bloom et al. 2014a). 
Taken together, these bad performances urge decision makers to change deeply their education model ${ }^{1}$. International Development Agencies are currently focusing with African countries on reforming education systems and building human capital as the keys for the takeoff of the continent in the next decades (Soucat and Ncube, 2014, Oxford Analytica, 2013).

We think it is important to notice that bad performances of the African education system occur in a context of shortage and inefficient provision of energy. In fact, less than three in every ten people living in Sub-Saharan Africa (SSA) have access to electricity, compared to more than half in South Asia and 90 per cent in East Asia (Rault et al. 2014; Eberhard, 2013). The combined power generation capacity of the 48 countries of SSA (excluding South Africa) is about 80 gigawatts (GW); a single country, Spain, has more (Eberhard, 2013; CBC, 2013).

Many theoretical channels may explain potential links between energy and education in Africa. For instance, access and use of energy, especially electricity, have evident impacts on education performance. Access to electricity impacts also attendance to school (especially for girls). Electrification make easier for girls to do their homework in the evening. Access to electricity impacts the cooking activity and wood collection for cooking. This can also easier for their mothers to help them. The inability of several countries in Africa to reach Universal primary education may be linked to the lack or absence of electricity, especially in rural areas. At the same time, poor education quality and outcomes especially in secondary and higher education may explain and be explained by the difficult energy provision situation. How can African universities or technical and professional education perform well in a context of shortage of electricity and energy and how can Africa resolve the situation without good universities and experts?

Empirically, there is growing evidence around the fact that energy use (especially electricity access and use) has an impact on education worldwide. In the context of developing countries, most of the literature shows a positive link between education outcomes and access to energy. Saqib (1995), reports that the electrification of neighborhoods increases the willingness of households to pay for education in Pakistan. The Netherlands Energy Research Foundation (ECN) found that access to electricity increases time spent on reading

\footnotetext{
${ }^{1}$ The African Development Bank (AfDB, 2014), for example, urges decision makers to move to a new education model (NEMA). According to this model, Africa needs to make six complementary changes: investing and using ICT in Education, Promoting of critical thinking, Promoting Public-Private Partnerships, More participatory education with all the stakeholders, Accountability, linking the education system to the job market and
} 
and writing in Nepal (Nieuwenhout et al. 1999). In the case of rural Philippines, Barnes et al. (2002) show that children in households with electricity stayed at school for an average of two more years than those in households without electricity. Valer et al. (2014) show that Amazonia (Puna) access to electricity improved education outcomes through prolonged hours of school and access to Internet.

As far as Africa is concerned, results from available research are heterogeneous and do not allow for clear conclusions. Indeed, while some works show a positive effect of energy on education in Africa, others report negative links. For instance, the Netherlands Energy Research Foundation (ECN) found that access to electricity decreased time spent on studies in Tunisia in favor of time spent on watching TV (Nieuwenhout et al. 1999). However, the authors recognize that television permits to improve the general knowledge of the situation in the country, and foreign language skills. In the case of Namibia, James et al. (1999) and Wamukonya and Davis (1999) show that electricity brings an important improvement of lives and allows for spending more time studying. However, teachers consider that these improvements are not linked directly to school results. In the case of Zambia, Gustavsson (2006) shows that children in a household with access to solar energy spend more time doing their homework as compared to neighbors' children, who do not have access to this energy. In Madagascar, Daka and Ballet (2011) show that electrification enables children to do their homework in the evening and to keep up with their school's work ${ }^{2}$.

The objective of this paper is to extend this ongoing literature ${ }^{3}$ by bringing fresh analytical and empirical evidence on the links between energy and electricity and education in Africa. More precisely, we contribute to the energy-education debate in Africa by proposing four innovations. First, most of this literature focus on primary education or does not refer to the level of schooling. While these effects are well discussed in primary education; they are less discussed in secondary and higher education. It seems difficult to imagine a higher education system without electricity and energy. Teaching chemicals, natural science, medicine, pharmaceuticals need experiments. These experiments will not be conducted without energy. Only social sciences and some disciplines like mathematical do not need experimentation. At the same time, it is difficult to imagine higher education without access to ICT. Lack or absence of energy may impact deeply the quality of education (especially secondary and tertiary).

\footnotetext{
${ }^{2}$ Recently, Ouedraogo 2013 has tried to link energy consumption to human capital formation.

${ }^{3}$ Chen et al. 2013, Dias et al. 2004 and 2006
} 
Second, the existing literature has mostly focused on case studies (a population of a village or a case study in a given country) and little is known about the validity of this relationship at a macro-economic level for a panel of countries. We look at the evidence of this relation for the last 20 years in 16 African countries.

Third, most of this literature restrict the causality to electricity consumption and do not take into account the total energy use. Energy use permits to take into account all the other energy uses that may impact secondary and tertiary education. For instance, energy use permits to take into account the energy dedicated to transportation of students to secondary and higher education. It also takes into account the productive uses of energy and by this the link between secondary and higher education and private sector in matters of trainings and job creation.

Finally, our econometric approach contains a novelty since we employ the panel Granger causality testing approach of Konya (2006) that is based on SUR systems and Wald tests with country specific bootstrap critical values. Specifically, this approach allows to testing for Granger-causality between energy consumption and education on each individual panel member separately in a panel framework by taking into account the possible contemporaneous correlation across African countries.

The remainder of the paper is structured as follows. Section 2 presents the conceptual framework. Section 3 exposes our methodology and characterizes our data. Section 4 reports and discusses the results. Section 5 summarizes the mains findings and discusses the policy implications of our work.

\section{Energy and education: a conceptual framework}

We identify at least six main channels through which energy use may impact education outcomes. We divide them into three categories. The first one is related to the change in the school environment. The second one reflects the home conditions to prepare homework. The third one reflects change in the health of students, which impacts their education outcomes.

\subsection{Improvements of working and learning conditions at schools}

Energy access improves working and learning conditions in schools and other training facilities. Electricity provision (part of energy use) can improve the school attendance by teachers and students. One of the main problems in African education is the absenteeism of 
teachers. It is reported that in some countries this can reach a pick of $70 \%$. Providing electricity in schools can increase the teachers' and students' attendance.

Energy can also improve the quality of schools and build connections to surrounding communities. Schools can access Internet and ICT allowing wide use of learning materials available for free. In all parts of Africa, the connectivity is improved, thanks to the mobile phone coverage. Using the capacity of these leapfrogging technologies to increase access and quality of Africa education is highly recommended.

The increase of energy use and electricity consumption in Africa can change the conditions of the learning experience and help to address its problems in terms of quantity and quality education.

\subsection{Improvement of home conditions of education}

Access to electricity and to energy improves the conditions of working at home. First, children can extend their homework by night and will be more able to follow classroom interactions. Second, some of the time dedicated to homework made by children as collecting woods for cooking will be substituted by learning and education activities time. This is particularly true for girls. As energy and electricity provision increases the parents (especially the mothers) will also be more involved in helping their kids for their homework.

Access to energy increases the available time of children for education. At the same time, access to energy can shorten the transport time. It is always reported that children are walking several kilometers before reaching their schools. By doing so they spent a lot of time in transport. As energy use increases it reflects also an increase availability of transportation and lowering time of transport.

Another important impact of availability of energy is access to ICT. Accessing to computer and to Internet is helping African students to access to worldwide knowledge for free. This may improves their outcomes if the needed skills are acquired. This is also the case for television watching. It may improve the general cultural skills as well as language skills as reported by some studies. Some externalities are also reported when neighbors access to energy. The education outcomes are improved by the neighbors' children.

In sum, increasing access to electricity improves the time spent on education, the condition under which the learning is done and the availability of the family for help. Other divides like TV and ICT can foster the learning process. 


\subsection{Improvement of general conditions of learning}

Increasing access to energy improves health conditions of children (WHO, 2006). Access to energy allows access to refrigeration and to medicines. For example, it is always reported that lack of energy implies that most of vaccines are "out-of-date". Absenteeism is lowered when health conditions are improved. More than that, the cooking conditions are improved allowing better nutrition and better health for children allowing them to focus on education. Access to energy helped several governments to set special programs of giving food for the students in order to increase their attendance to schools and to lower the absenteeism.

As energy becomes more available, access to classrooms and training usually picks up, allowing greater accumulation of human capital and better skills (WEF, 2012). But there is little empirical evidence on this relationship in Africa. We will try to challenge this issue in the next section by examining the impacts of energy use and electricity provision on primary, secondary and higher education.

\section{Methodology}

Methodologically, our paper contributes to the literature with a bootstrap panel analysis of causality relationships between energy use or electricity consumption and education for a sample of 16 African countries: Algeria, Benin, Cameroon, Democratic Republic of Congo, Egypt, Ethiopia, Ghana, Kenya, Morocco, Mozambique, Nigeria, Senegal, South Africa, Tanzania, Tunisia and Zambia. Data are annual over the period 1971-2010 and sourced for World Development Indicators. We first estimate a panel Vector AutoRegressive (VAR) model and then implement the panel-data approach of Kónya (2006), based on Seemingly Unrelated Regressions (SUR) system and Wald tests with country specific bootstrap critical values. In the specific framework we use, we allow for cross-country correlation, without the need of pretesting for unit roots and cointegration (as in Phillips, 1995).

We propose to apply a bivariate finite-order vector autoregressive (VAR) model to energy use or electricity consumption (E) and education (EDUCATION): ${ }^{4}$

\footnotetext{
${ }^{4}$ We are grateful to L. Kónya for providing his TSP codes, which we have adapted for our analysis.
} 


$$
\left\{\begin{array}{c}
E_{i t}=\alpha_{1 i}+\sum_{j=1}^{p_{1 i}} \beta_{1, i, j} E_{i t-j}+\sum_{j=1}^{p_{2, i}} \gamma_{1, i, j} \operatorname{EDUCATION~}_{i t-j}+\varepsilon_{1, i, t} \quad t=1, \ldots, T i=1, \ldots, N \quad(1 a) \\
\text { EDUCATION }_{i t}=\alpha_{1 i}+\sum_{j=1}^{p_{1 i}} \beta_{2, i, j} E_{i t-j}+\sum_{j=1}^{p_{2, i}} \gamma_{2, i, j} \text { EDUCATION }_{i t-j}+\varepsilon_{2, i, t} \quad t=1, \ldots, T i=1, \ldots, N
\end{array}\right.
$$

, where $i(i=1, \ldots, N)$ and $t(t=1, \ldots, T)$ denote respectively the country, and the period, whereas $j$ indicate the lag, and $p_{1 i}, p_{2 i}$ and $p_{3 i}$, represents the maximum lags in equations (1a) and (1b). $\varepsilon_{1, i, t}$ and $\varepsilon_{2, i, t}$, are assumed to be white-noises and can be correlated with each other for a specific country, but not across countries.

Then, the above VAR is estimated using Zellner's Seemingly Unrelated Regressions (SUR), because potential interactions may affect individual regressions through contemporaneous correlation $^{5}$ within equations (1a) and (1b). Finally, Granger causality is investigated with Wald tests with critical values generated for each country by simulation and bootstrapping techniques.

In equations (1a) and (1b) of the VAR, in country $i$ there is one-way Granger-causality from EDUCATION to $\mathrm{E}$ if in the first equation not all $\gamma_{1, i}$ are zero but in the second all $\beta_{2, i}$ are zero; there is one-way Granger-causality from E to EDUCATION if in the first equation all $\gamma_{1, i}$ are zero but in the second not all $\beta_{2, i}$ are zero; there is two-way Granger-causality between E to EDUCATION if neither all $\beta_{2, i}$ nor all $\gamma_{1, i}$ are zero; and there is no Granger-causality between E to EDUCATION if all $\beta_{2, i}$ and $\gamma_{1, i}$ are zero. $^{6}$

This procedure has at least three advantages. Firstly, it does not assume that the panel of countries is homogenous, so it is possible to test for Granger-causality on each individual country separately. Secondly, this panel methodology which is an extension of the approach proposed by Phillips (1995) for testing for Granger non-causality on time series data in VAR models expressed in levels, does not also necessitate the use of pre-tests for a unit root or cointegration. However, it still necessitate determining the model's optimal lag length which can easily be done using the Akaike (AIC) or Schwarz Information Criterion (SIC). This is a very nice property since it is now well known that unit-root and cointegration tests have low

\footnotetext{
${ }^{5}$ Since there exists very strong economic links between countries of Africa, this assumption seems to be very relevant here.

${ }^{6}$ It has been pointed out by Kónya (2006) that this definition was associated to one-period-ahead Granger causality.
} 
power in finite samples, and different tests may lead to opposite conclusion. Thirdly, this panel Granger causality approach enables the applied economist to know for how many countries and for which countries of the panel there exists one-way, two-way, or no Grangercausality.

\section{Results}

The implementation of the AIC and SIC criteria in a model initially incorporating a maximum lag length of 3 leads to the selection of a VAR(1) model in accordance with data properties. Besides, misspecification tests report in this case no deviation from usual underlying assumptions. We then use the Breusch-Pagan Lagrange multiplier statistic (1980) to test for the diagonal error variance-covariance matrix. We report that within the different systems considered, the no contemporaneous correlation null hypothesis is always rejected at the five percent level of significance. This which provides clear evidence in favour of the use of SUR estimators which lead to more efficient parameter estimates than Ordinary Least Squares.

We start by discussing the results for Energy use in general, then, we move to a specific discussion for electricity. Our main empirical findings are summarized in Tables 1.a to 6.b in Appendix.

\subsection{Causality analysis between Energy Use and Education}

Our results show four cases of interest that need to be discussed.

\section{(a) Energy use causes Education}

Our results show that energy use Granger causes education in eight out of 16 studied countries. Unidirectional Granger causality from energy use to primary education for is found in the case of Cameroon. Positive unidirectional Granger causality from energy use to secondary education in DRC, Ghana, Senegal and Tanzania is found. In contrast, negative unidirectional Granger causality from energy use to secondary education in Cameroon and Ethiopia is found. There is positive unidirectional Granger causality from energy use to tertiary education in DRC, Benin and Ethiopia. Negative unidirectional Granger causality from energy use to tertiary education in Zambia is found. 
Granger causality in primary education is found only in two Fragile States ${ }^{7}$ (Cameroon and Ethiopia), while low income's countries like Ghana, Senegal and Tanzania exhibits this causality for secondary education.

Our results show that energy use has an impact on enrolment in Africa. But this effect varies among countries and according to the level of education. While we expected to get a more important effect on primary education, we found that only Cameroon meets these expectations. We suggest to possible explanations for this finding. First, some of the studied countries have already reached universal primary education and enrolment in primary education is closer to $100 \%$ and so the effect of energy on primary education is marginal. Second, for other countries in our sample energy use dynamics is not strong enough to impact primary education enrolment. As for secondary and tertiary education, we think that an increase in energy use may lead to an increase in economic activity and students may be attracted by working in the productive sector instead of increasing their skills in the education system. This is found in the case of Zambia for higher education and in Cameroon and Ethiopia for secondary education.

\section{(b) Education causes energy use}

There is evidence of a unidirectional Granger causality from primary education to energy use for Benin, Democratic Republic of Congo, Kenya, Mozambique, and Tanzania. It can be also noticed a unidirectional Granger causality from secondary education enrolment to energy use for Algeria, Kenya, Mozambique, and Zambia. A unidirectional Granger causality from higher education enrollment to energy consumption for Algeria, Cameroon, Egypt, Kenya, Mozambique, and Tanzania is also found.

Since education and enrolment are positively associated with GDP per capita, increasing enrolment in education often leads to increasing GDP per capita implying an increase in the consumption and use of energy. Our results confirm this expectation for most Sub-Saharan countries of our sample. Recent works has shown the strong links between energy use and economic growth in Africa (among others see Esso, 2010; Rault et al. 2012; Arouri et al. 2014). Our results show strong evidence that as enrolment and education are

\footnotetext{
${ }^{7}$ A fragile state is defined as "a region or state that has weak capacity to carry out basic governance functions, and lacks the ability to develop mutually constructive relations with society” (OCDE, 2013). The list of Fragile States contains Angola, Burundi, Cameroon, Central African Republic, Chad, Comoros, Democratic Republic of Congo, Republic of Congo, Côte d'Ivoire, Eritrea, Ethiopia, Guinea, Guinea-Bissau, Kenya, Liberia, Malawi, Niger, Nigeria, Rwanda, Sierra Leone, Somalia, South Sudan, Togo, Uganda and Zimbabwe (OECD 2013).
} 
strengthened in Africa, an economic transformation will occur implying more energy use in the future.

\section{(c) Bidirectional causality between education and energy use}

Our results show evidence of bidirectional Granger causality for Ethiopia, at the $10 \%$ or lower level of significance between energy use and primary education. There is also evidence of bidirectional Granger causality for Ethiopia, and Tanzania, at the $10 \%$ or lower level of significance between secondary education enrollment and energy use. Our results also show evidence of bidirectional Granger causality for Benin, and Ethiopia, at the 10\% or lower level of significance between higher education and energy use.

This finding confirms and strengthens the previous discussion about the mutual enforcement aspect of education and energy use. As the economy is transforming, GDP per capita increases allowing poor people to educate their children and to ask them to do less homework for the households needs. This is particularly true for girls. As the education level of the society increases, the economic structure changes and more complex goods and services are produced and consumed which requires more and more energy use. This circle is expected to be found in most African countries in the next decades.

\section{(d) No causality between energy use and education}

We find that for four countries there is no causality between energy use and education enrolment, whatever the level of significance is. This is the case for Morocco, Nigeria, South Africa, and Tunisia. The four countries are considered as middle income countries and are among the best performers in matter of education in the continent. Their education enrollment rates are certainly depending on other variables.

For the most advanced African countries (in terms of GDP per capita), we found that there is no causality. However, this does not exclude the existence of nonlinear forms of causal relationships. In other terms, the circle between education and energy use may work until some threshold. This needs to be further investigated in our future works. 


\subsection{Electricity consumption and Education}

In order to deepen our discussion, we examine more precisely electricity consumption. Electricity consumption is one of the components of energy use. It provides more information about the evolution of electrification of Africa and its impacts on education.

Four cases need to be discussed:

(a) Unidirectional causality from electricity consumption per capita to education

Our results show clearly that electricity has an education outcome. We found that this relationship is positive and significant in primary education in Ethiopia, Kenya and South Africa. The relation is also positive and significant in secondary education for Kenya and Senegal. The most important findings concern the tertiary education. The relation is positive and significant in Algeria, Ethiopia, Kenya, Nigeria, Senegal, and Tanzania. However, we found a negative relationship for secondary education in Zambia.

Our analysis reveals a strong link between education and electricity per capita consumption in seven out of the 16 studied African countries. In Kenya this link is found for all the education sectors while Senegal and Ethiopia are showing a strong relationship in two sectors. Our empirical findings also suggest a strong link between building human capital and energy use. As energy use (especially electricity) is expected to increase in the near future, its impacts on education in Africa are expected to be important. Sustainable Energy for all (SE4ALL) ${ }^{8}$ needs to be considered as first target in order to increase education outcome in Africa (Banarjee et al. 2014).

The case of Zambia is puzzling. Our findings confirm previous results about energy use. In fact as the energy use and electricity consumption are growing, the economic activity is expanding in Zambia leading to increase the opportunities for jobs for youth. They prefer working instead of schooling.

\section{(b) Unidirectional causality from education to Electricity per capita consumption}

The second causality is also working. As Africa is investing in education, the electricity per capita consumption increases. A positive causality from education to electricity

\footnotetext{
${ }^{8}$ See the Energy Policy special issue 2012.
} 
consumption is found in Cameroon and DRC for primary education. A positive relationship is also found from education to electricity consumption in Algeria, Cameroon and Mozambique. The relationship is strengthened in Algeria, Cameroon, Tunisia, Mozambique and Senegal for higher education. As the level of education increases the economy is able to produce more complex goods allowing an increase in the GDP and an increase in the per capita consumption of electricity. Our results show also a negative relationship between electricity consumption and education in Zambia.

Several explanations may be advanced. Kenya and Ethiopia are fast growing economies in Africa. Education is a proxy of human capital. As education increases the economy produces more goods and services implying increasing revenues and since then increasing levels of electricity consumption. South Africa is a special case.

In Kenya, Senegal and Nigeria the causality is positive. As the electricity consumption per capita increases the enrollment in secondary education increases. Behind this dynamics electricity per capita is correlated to revenue. The more families increase their revenues the more they send their children to secondary schools. At the same time, the availability of electricity can reduce child labor and homework especially for girls allowing them to be more enrolled.

One puzzling result is the one found for Zambia. As electricity per capita increases, the enrollment in secondary education decreases. Increased per capita electricity consumption is increased mainly due to an increase to productive sector electricity use. In turn the productive sector requires more workforces without qualifications and this leads to less enrollment in the secondary education.

The Zambian case needs further investigations. An increase in higher education and secondary education enrollment decreases the electricity consumption per capita. This is puzzling and may be due to an expansion in education without taking into account the needs of the economy in the labor market.

A demographic effect is probably playing a significant role in this case. The high level of increase of the population in the last two decades leaded to a massive enrollment in secondary and tertiary education levels and in the same time to the fall of the electricity consumption per capita due to the low increase of electricity production. 
(c) Bidirectional Causality between Education and electricity consumption per capita

The results of the causality tests between electric consumption and primary education show no bidirectional Granger causality for, at the $10 \%$ or lower level of significance. No bidirectional Granger causality between secondary education and electricity per capita, at the $10 \%$ or lower level of significance is found. However, our results show that the causality tests between electric consumption and tertiary education show bidirectional Granger causality for Algeria, and Senegal, at the $10 \%$ or lower level of significance.

Bidirectional causality implies that a virtual circle exists between electricity consumption and education. Since the enrolment in higher education increases, the economy may absorb more skilled persons and make its transformation for more added-value production of goods and services. Since then, the GDP increases, and the salaries increase also. GDP per capita increases allow people to consume more electricity. This additional consumption of electricity benefits schools and students and increase enrolment in secondary education allowing more people in higher education. The phenomenon is observed nowadays in Algeria and Senegal and may be generalized to all parts of Africa in the next decades. The enrolment in higher education is expected to increase significantly in the near future in Africa.

(d) No causality between Education and electricity consumption per capita

We find that for four countries there is no causality between energy use and education enrolment, whatever the level of significance is. This is the case for Benin, Egypt, Ghana, and Morocco. Indeed, the four countries are heterogeneous, geographically distant and there is no particular feature to be considered. Their education enrollment rates are certainly depending on other variables. However, we need to mention that for those countries we found that the energy use matters for education at least in one level of education. 


\section{Policy implication and concluding remarks}

The aim of this paper was to study the causality between from the one hand (i) energy use and education and from the other hand (ii) between electricity consumption and education in Africa. Our results show clear link between energy and education outcomes as our conceptual framework suggests. Issues such as universal access to education often cannot be adequately addressed because schools and the community lack access to electricity or energy. As with health practitioners, lack of electricity is a disincentive for teachers to live in such areas. Children's education is also impaired by inadequate illumination in poor households that rely on candles or kerosene lamps. Following our results four distinctive policies recommendations are made.

First, Electricity-access strategies should target public facilities such as schools, which benefit the whole population in an area, so that they can provide essential services needed to improve life quality and generate income. Investment programs in education sectors are often not aligned with those for provision of electricity service so that these facilities are not properly equipped with energy services. Our results show that energy use and electricity consumption have an impact on education as expected. Based on these results, and as Africa is fast growing its energy consumption and use is expected to increase hugely in the next decades, we can expect an important impact on education enrollment. The continent has to invest in energy to achieve its goal of education for all and improve its situation as regard secondary and tertiary education. Increasing availability of energy and electricity imply extending schools hours, night homework, access to Internet and to virtual learning objects and less homework for children especially girls. The last mile policy consisting in electricity provision of schools in all new projects seems an appropriate policy in order to accelerate these benefits to the Continent, especially in Sub-Saharan Africa.

Second, more energy is required in rural areas to enhance education. Indeed, there are big differences between urbanized areas and rural areas in matter of energy use and electricity consumption. These differences impact education outcomes. The regional differences in matter of education outcomes increase the rural to urban migration. Extending the electricity provision needs first to look at rural Africa in order to balance inequalities. Africa is increasing its urbanization and $60 \%$ of the Africans will be urban dwellers. This urbanization process is not as beneficial as in the other parts of the world, due too anarchic expansion of the towns without planning and appropriate policy especially in matter of provision of basic 
facilities. As a consequence, provision of electricity and energy in rural Africa, can help to maintain the rural dwellers in rural areas and better manage the urbanization process. Provision of rural schools with electricity first, can be a good incentive for rural to stay.

Third, investing in education improves the energy situation in Africa. Indeed, our findings show that there is increasing evidence of the reversal causality. As Africa is investing in Education, educated people have more needs in matter of energy. Educated people have more requirements about their living standard especially for transport, education, health and leisure. Africa is facing two separate effects: from the one hand, a quantitative effect with an important rate of birth, the continent is becoming the most populated continent in the next century passing from 1 billion to 2.3 billion inhabitants in 2050. From the other hand, Africa is experiencing a qualitative effect (changing the living style). Educated people have increasing needs in matter of energy. Working together, these effects can impact positively education since their living standards are changing thanks to education.

Finally, Africa should invest more in renewable energies. Technological evolutions allow developing nowadays' renewable energies out of the grid. These technologies suit very well Africa, especially rural areas. Targeting schools in provision of electricity with renewable energies can enhance the sustainability of African economy and spread the sustainable development model in schools. Africa availability in matter of renewable energies such solar, wind, geothermal and biomass are very important and there is a need to link the development of these technologies with basic facilities like schools. 


\section{References}

African Development Bank (2014), Human Capital Strategy. Tunis.

Banerjee, Sudeshna Ghosh; Bhatia, Mikul; Portale, Elisa; Angelou, Nicolina; Dorner, Dan; Schers, Jules; Selmet, Nora; Dora, Carlos; Adair-Rohani, Heather; Wilburn, Susan; Bruce, Nigel; Trace, Simon; Jaques, Ivan; Sarkar, Ashok; Bushueva, Irina; Inon, Javier Gustavo; Benoit, Philippe; Tromop, Robert; Pasquier, Sara Bryan; Cozzi, Laura; Kesicki, Fabian; Park, Taejin; Trudeau, Nathalie; Zyzniewski, Anna; Azuela, Gabriela Elizondo; Frankl, Paolo; Brown, Adam; Dobrotkova, Zuzana; Gielen, Dolf; Kempener, Ruud; Lins, Christine; Otto, Martina; Subratty, Djaheezah (2014) Global tracking framework. Sustainable energy for all. Washington DC. World Bank Group.

Bongjoh, F., Foko, A.B., Gueye, M., Ndem, F. 2014. Making National Education Systems Work for Africa. In One Billion People, one billion opportunities: Building Human Capital in Africa. Soucat and Ncube (eds). Chapter 16. 247-260. African Development Bank. Tunis.African Development Bank. Tunis.

Breusch, T., and Pagan, A. (1980), “The Lagrange multiplier test and its applications to model specification in econometrics”. The Review of Economic Studies, 47(1): 239.253.

Bloom, D., Canning, D., Chan, K., and Luca, D. L. 2014a. Higher Education and Economic Growth in Africa. International Journal of African Higher Education.

Bloom, D., Humair, S., Rosenberg, L., Sevilla, J.P., and Trussell, J. 2014b. Capturing a Demographic Dividend: Source, Magnitude and Realization, in "One Billion People, One Billion Opportunities” Soucat, A., and Mthuli, N. (ed.) (Chapter 2), African Development Bank. Tunis. P. 23-39.

CBC, 2013. Africa infrastructure investment report, Commonwealth Business Council.

Chen, K-L., Huang, S-H., Liu, S-Y. (2013), “Devising a framework for energy education in Taiwan using the analytic hierarchy process”, Energy Policy 55 (2013) 396-403.

Daka, K.R. Ballet, J. (2011), Children's education and home electrification: A case study in northwestern Madagascar, Energy Policy, 39, 2866-2874.

Dias, R. A., Mattos, C. R., and Balestieri, J.A.P. (2004), "Energy education: breaking up the rational energy use barriers”, Energy Policy 32, 1339-1347.

Dias, R. A., Mattos, C. R., and Balestieri, J. A. P. (2006), “The limits of human development and the use of energy and natural resources”, Energy Policy 34, 1026-1031.

Eberhard, A. (2013). Africa’s Power Crisis. CBC Africa Infrastructure Investment Report. Pp 81-87.

Esso, L.J., (2010), “Threshold cointegration and causality relationship between energy use and growth in seven African countries”. Energy Economics 32, 1383-1391. 
Energy Policy special issue, (2012) Universal access to energy: getting the framework right, Energy Policy Vol. 47.

Gustavsson, M., 2006. With time comes increased loads - an analysis of solar home system use in Lundazi, Zambia. Renewable Energy, 29, 1059-1072.

Hayward, F. M., and Ncayiyana, D. J. 2014. Confronting the challenges of graduate education in sub-saharan Africa and Prospects for the future. International Journal of African Higher Education.

Hungi, N., F.W. Thuku (2010), «Variation in reading achievement across 14 southern African school systems: which factors matter?», International Review of Education, 56(1).

James, B., Nakatana, M., Rudek, B., (1999), «Socio-Economic Impacts of Rural Electrification in Namibia: Report 2: The Impact of Electrification on Rural Health Care Facilities, Education, and Small Businesses ». Energy and Development Research Centre, University of Cape Town, Cape Town, South Africa, p. 52.

Kónya, L. (2006), Exports and growth: Granger causality analysis on OECD countries with a panel data approach. Economic Modelling, 23, 978-982.

Nieuwenhout, F.D.J., van Dijk, A.L., van Dijk, V.A.P., Lasschuit, P.E., van Roekel, G., Arriaza, H., Hankins, M., Sharma, B.D., Wade, H., 1999. Monitoring and evaluation of solar home systems: experiences with applications of solar PV for households in developing countries, ECN-C-00-089. Energieonderzoek Centrum Nederland (ECN), p. 157. http://www.ecn.nl/library/reports/1999/c00089.html.

OCDE (2011), «PISA 2009- Plus Results: Performance of 15-yearolds in reading, mathematics and science for 10 additional participants », Paris.

OECD (Organisation for Economic Co-operation and Development). 2013. Fragile States 2013: Resource Flows and Trends in a Shifting World. Paris: OECD Publishing. www.oecd.org/dac/incaf/FragileStates2013.pdf.

Ouedraogo, N. S. (2013), "Energy consumption and human development: Evidence from a panel cointegration and error correction model”, Energy 63 (2013), 28-41.

Oxford Analytica. (2013). “Africa Higher Education Growth Leaves Quality Concerns.” Oxford Analytica Daily Brief, December 19.

Phillips, P.C.B. (1995). Fully Modified Least Squares and Vector Autoregression, Econometrica, vol 63, 5, pp 1023-1078.

Rault, C., M. Arouri, Ben Youssef, A., Dubois, U., Mhenni, H., and Tchapga, F. (2014) Developing access to modern energy sources. In in "One Billion People, One Billion Opportunities” Soucat, A., and Mthuli, N. (ed.) (Chapter 8), African Development Bank. Tunis. P. 109-130.

Saqib, Najam-us, 1995. Willingness to pay for primary education in rural Pakistan, PhD Thesis, Johnhopkins University. 
Soucat, A. and Ncube, M., 2014. One billion opportunities: The changing landscape of human capital in Africa. in One Billion People, one billion opportunities: Building Human Capital in Africa. Soucat and Ncube (eds). Chapter 1. 1-23. African Development Bank. Tunis.

UNDP. 2006. Expanding access to modern energy services; replicating, scaling up and mainstreaming at the local level. Lessons from community-based energy initiatives”, S. Gitonga and E. Clemens (eds.), United Nations Development Programme, New York.

UN Habitat. 2014. The state of African cities 2014. Re-imagining sustainable urban transitions.

United Nations, 2007. Energy for Sustainable Development: Policy Options for Africa, UNENERGY/Africa publication to CSD15, www.iaea.org/OurWork/ST/NE/Pess/.../unenergy_africa_pub.pdf

UNDP 2006. Expanding access to modern energy services; replicating, scaling up and mainstreaming at the local level. Lessons from community-based energy initiatives, $\mathrm{S}$. Gitonga and E. Clemens (eds.), United Nations Development Programme, New York.

UNESCO 2012. Education for All Global Monitoring Report 2012: Youth and skills: Putting Education to Work. Paris.

Wamukonya, L., Davis, M., 1999. Socio-Economic Impacts of Rural Electrification in Namibia: Report 1: Comparisons between Grid, Solar and Unelectrified Households. Energy and Development Research Centre, University of Cape Town, Cape Town, South Africa, p. 24.

World Economic Forum (2012), Energy for Economic Growth. Industry Agenda. Energy vision 2012 update. Prepared in partnership with IHS CERA.

World Health Organization (WHO), 2006. Fuel for life. Household energy and health. Geneva.

World Health Organization (WHO), 2014. Household air pollution and health, Factsheet n²92, updated March 2014. 


\section{$\underline{\text { Appendix }}$}

Table 1a - Granger causality tests from Education to Energy Use over the period 1971-2010, bivariate (ENERGY USE, EDUCATION1) model $^{9}$

\begin{tabular}{llllll}
\hline \hline & Estimated & Test Statistic & \multicolumn{3}{c}{ Bootstrap critical values } \\
\cline { 4 - 6 } & Coefficient & & $1 \%$ & $5 \%$ & $10 \%$ \\
\hline Algeria & 2.0697 & $2.6495^{*}$ & 4.4621 & 3.5561 & 2.5538 \\
Benin & 0.2601 & 1.1019 & 2.6303 & 2.1670 & 1.7117 \\
Cameroon & -0.1687 & -1.0805 & 2.8323 & 2.2196 & 1.7960 \\
Democratic Republic of Congo & 0.2319 & 1.2281 & 4.5828 & 3.6944 & 2.9742 \\
Egypt & 0.9696 & 2.1037 & 6.9743 & 5.8223 & 4.8133 \\
Ethiopia & 0.8071 & $2.5932^{*}$ & 4.5960 & 3.5057 & 2.3189 \\
Ghana & -0.1061 & -.29313 & 2.3922 & 1.8968 & 1.5036 \\
Kenya & 0.2227 & $2.4377^{*}$ & 3.2227 & 2.5256 & 2.0373 \\
Morocco & 0.1178 & .35384 & 7.0465 & 5.7252 & 4.7515 \\
Mozambique & 0.5460 & $2.0520^{*}$ & 2.8425 & 2.2666 & 1.7946 \\
Nigeria & 0.0151 & .04710 & 4.4953 & 3.6912 & 2.9652 \\
Senegal & 0.0938 & .41818 & 2.9199 & 2.3713 & 1.9145 \\
South Africa & 1.3103 & 1.0042 & 2.5015 & 2.0234 & 1.6175 \\
Tanzania & 4.9015 & $6.2278^{* * *}$ & 3.5474 & 2.8869 & 2.3113 \\
Tunisia & 0.6934 & 1.2293 & 5.8708 & 4.7124 & 3.8438 \\
Zambia & -10.7245 & $-4.6473 *$ & 6.1213 & 5.0675 & 4.1180 \\
\hline \hline
\end{tabular}

***. **. *: significance at the $1 \%$. $5 \%$ and $10 \%$ levels, respectively.

$\mathrm{H}_{0}$ : EDUCATION1 does not cause ENERGY USE.

Table 1b - Granger causality tests from Energy Use to Education over the period 1971-2010, bivariate (ENERGY USE, EDUCATION1) model

\begin{tabular}{llllll}
\hline \hline & Estimated & Test Statistic & \multicolumn{3}{c}{ Bootstrap critical values } \\
\cline { 4 - 6 } & Coefficient & & $1 \%$ & $5 \%$ & $10 \%$ \\
\hline Algeria & 0.0115 & 2.1702 & 5.7508 & 4.6538 & 3.6735 \\
Benin & -0.0104 & -1.0013 & 3.5644 & 2.8095 & 2.2125 \\
Cameroon & -0.0535 & $-3.9423 * * *$ & 3.9316 & 3.2179 & 2.6142 \\
Democratic Republic of Congo & 0.0333 & $2.6201^{* *}$ & 3.1008 & 2.4371 & 1.9587 \\
Egypt & -0.0064 & -1.1784 & 3.4595 & 2.7897 & 2.2702 \\
Ethiopia & -0.0247 & $-3.0264 * *$ & 3.7896 & 2.9474 & 2.3844 \\
Ghana & 0.0332 & $4.1372 * * *$ & 3.4502 & 2.7362 & 2.2110 \\
Kenya & -0.0113 & -.53202 & 3.7021 & 2.9379 & 2.4102 \\
Morocco & 0.0124 & 2.7193 & 7.7527 & 6.3407 & 5.3160 \\
Mozambique & 0.0006 & .35164 & 3.6295 & 2.9240 & 2.3445 \\
Nigeria & 0.0256 & 2.2660 & 6.3956 & 5.3357 & 4.4075 \\
Senegal & 0.0157 & $2.6792 *$ & 3.8147 & 3.1015 & 2.4779 \\
South Africa & 0.0014 & .99924 & 4.1493 & 3.3341 & 2.6701 \\
Tanzania & 0.0342 & $2.6140 * * *$ & 0.7481 & 0.6218 & 0.5212 \\
Tunisia & 0.0195 & 3.9608 & 11.9014 & 10.2717 & 8.9904 \\
Zambia & -0.0011 & -.64008 & 6.5473 & 5.5510 & 4.6094 \\
\hline \hline
\end{tabular}

***. **. *: significance at the $1 \% .5 \%$ and $10 \%$ levels, respectively.

$\mathrm{H}_{0}$ : ENERGY USE does not cause EDUCATION1.

${ }^{9}$ EDUCATION1 denotes the primary education enrolment level. 
Table 2a - Granger causality tests from Education to Energy Use over the period 1971-2010, bivariate (ENERGY USE, EDUCATION2) model ${ }^{10}$

\begin{tabular}{lllcll}
\hline \hline & Estimated & Test Statistic & \multicolumn{3}{c}{ Bootstrap critical values } \\
\cline { 4 - 6 } & Coefficient & & $1 \%$ & $5 \%$ & $10 \%$ \\
\hline Algeria & 2.7872 & $1.8888^{*}$ & 2.6512 & 2.1351 & 1.7187 \\
Benin & 2.0429 & $2.0121^{* * *}$ & 2.2809 & 1.8201 & 1.4832 \\
Cameroon & -1.4539 & $-2.3273^{* * *}$ & 2.0587 & 1.6398 & 1.3072 \\
Democratic Republic of Congo & 0.0536 & .05686 & 3.5276 & 2.7706 & 2.1710 \\
Egypt & 1.6226 & $2.5722^{*}$ & 3.8100 & 3.1093 & 2.5110 \\
Ethiopia & 6.1473 & $2.5989^{* *}$ & 2.9227 & 2.2552 & 1.7520 \\
Ghana & 0.5002 & .44875 & 2.2514 & 1.7257 & 1.3617 \\
Kenya & 2.6419 & $2.3596^{*}$ & 2.9768 & 2.3955 & 1.9556 \\
Morocco & -0.2737 & -.35239 & 5.9800 & 4.8322 & 3.9621 \\
Mozambique & 3.3635 & $2.4950^{* *}$ & 2.7381 & 2.2145 & 1.8018 \\
Nigeria & -0.3795 & -.51107 & 2.5690 & 2.0899 & 1.6953 \\
Senegal & 0.5292 & .77112 & 2.8316 & 2.2621 & 1.8416 \\
South Africa & -0.2763 & -.08596 & 2.8293 & 2.2702 & 1.8255 \\
Tanzania & 9.9616 & $5.2024 * * *$ & 2.4602 & 1.9932 & 1.5901 \\
Tunisia & 0.4882 & .52454 & 3.5761 & 2.8211 & 2.2644 \\
Zambia & -7.0433 & -.55129 & 5.2612 & 4.1761 & 3.5008 \\
\hline \hline
\end{tabular}

$* * * . * * . *$ : significance at the $1 \% .5 \%$ and $10 \%$ levels, respectively.

$\mathrm{H}_{0}$ : EDUCATION2 does not cause ENERGY USE.

Table $2 b$ - Granger causality tests from Energy Use to Education over the period 1971-2010, bivariate (ENERGY USE, EDUCATION2) model

\begin{tabular}{lllccc}
\hline \hline & Estimated & Test Statistic & \multicolumn{3}{c}{ Bootstrap critical values } \\
\cline { 4 - 6 } & Coefficient & & $1 \%$ & $5 \%$ & $10 \%$ \\
\hline Algeria & 0.0004 & .924407 & 4.7065 & 3.7499 & 3.0355 \\
Benin & 0.0077 & $3.15868^{* *}$ & 3.9993 & 3.1444 & 2.5314 \\
Cameroon & -0.0045 & -1.77149 & 3.6877 & 2.8919 & 2.3658 \\
Democratic Republic of Congo & 0.0150 & $4.32033^{* *}$ & 4.7818 & 3.8804 & 3.1253 \\
Egypt & 0.0053 & 1.92259 & 5.9614 & 4.7760 & 3.7206 \\
Ethiopia & 0.0082 & $9.35741^{* * *}$ & 4.3021 & 3.4653 & 2.7696 \\
Ghana & 0.0092 & 2.35269 & 4.8553 & 3.9257 & 3.2727 \\
Kenya & 0.0041 & 1.36508 & 3.9970 & 3.2402 & 2.6427 \\
Morocco & 0.0026 & 1.11339 & 3.9200 & 3.1397 & 2.5465 \\
Mozambique & -0.0002 & -.377730 & 4.0556 & 3.2159 & 2.6979 \\
Nigeria & 0.0063 & 2.88914 & 7.2754 & 5.9108 & 4.9129 \\
Senegal & -0.0006 & -.358799 & 4.6455 & 3.8135 & 3.0600 \\
South Africa & 0.0013 & 1.98684 & 4.3879 & 3.3816 & 2.6685 \\
Tanzania & 0.0012 & .304028 & 2.5410 & 2.0657 & 1.6937 \\
Tunisia & 0.0048 & 3.78156 & 8.7203 & 7.3524 & 6.2466 \\
Zambia & -0.0020 & $-3.13010^{* * *}$ & 2.7422 & 2.1501 & 1.7229 \\
\hline \hline
\end{tabular}

***. **. *: significance at the $1 \% .5 \%$ and $10 \%$ levels, respectively.

$\mathrm{H}_{0}$ : ENERGY USE does not cause EDUCATION2.

\footnotetext{
${ }^{10}$ EDUCATION2 denotes the secondary education enrolment level.
} 
Table 3a - Granger causality tests from Education to Energy Use over the period 1971-2010, bivariate (ENERGY USE, EDUCATION3) model ${ }^{11}$

\begin{tabular}{|c|c|c|c|c|c|}
\hline & \multirow{2}{*}{$\begin{array}{c}\text { Estimated } \\
\text { coefficient }\end{array}$} & \multirow[t]{2}{*}{ Test Statistic } & \multicolumn{3}{|c|}{ Bootstrap critical values } \\
\hline & & & $1 \%$ & $5 \%$ & $10 \%$ \\
\hline Algeria & 8.9889 & 3.8957 & 7.4535 & 6.1461 & 5.1269 \\
\hline Benin & 0.3441 & $2.3298 * *$ & 2.6044 & 2.0112 & 1.6533 \\
\hline Cameroon & 0.0979 & .55621 & 2.9683 & 2.3998 & 1.9038 \\
\hline Democratic Republic of Congo & -0.2714 & $-3.5097 * * *$ & 3.4982 & 2.8533 & 2.3139 \\
\hline Egypt & 0.9073 & 2.3885 & 4.1841 & 3.3471 & 2.7427 \\
\hline Ethiopia & 0.7055 & $4.3229 * * *$ & 3.0076 & 2.2887 & 1.8140 \\
\hline Ghana & 0.1651 & .34336 & 2.3356 & 1.8547 & 1.4639 \\
\hline Kenya & 0.4781 & $3.5939 * * *$ & 2.8055 & 2.2205 & 1.8074 \\
\hline Morocco & -0.1915 & -.69559 & 7.2248 & 5.9769 & 4.9760 \\
\hline Mozambique & 0.2215 & $2.8923^{* * *}$ & 2.7449 & 2.1961 & 1.7944 \\
\hline Nigeria & 0.3288 & .40985 & 2.7153 & 2.2237 & 1.7704 \\
\hline Senegal & 0.0372 & .41581 & 2.8277 & 2.2698 & 1.8293 \\
\hline South Africa & 3.7226 & .54487 & 3.1370 & 2.5265 & 2.0979 \\
\hline Tanzania & 0.1836 & $3.3849 * * *$ & 2.8960 & 2.3034 & 1.8174 \\
\hline Tunisia & 0.3444 & .42042 & 5.9547 & 4.8956 & 4.0138 \\
\hline Zambia & -0.0633 & -.14347 & 3.3394 & 2.7169 & 2.1878 \\
\hline
\end{tabular}

$* * * . * * . *$ : significance at the $1 \% .5 \%$ and $10 \%$ levels, respectively.

$\mathrm{H}_{0}$ : EDUCATION3does not cause ENERGY USE.

Table 3b - Granger causality tests from Energy Use to Education over the period 1971-2010, bivariate (ENERGY USE, EDUCATION3) model

\begin{tabular}{|c|c|c|c|c|c|}
\hline & \multirow{2}{*}{$\begin{array}{c}\text { Estimated } \\
\text { coefficient }\end{array}$} & \multirow[t]{2}{*}{ Test Statistic } & \multicolumn{3}{|c|}{ "Bootstrap critical values } \\
\hline & & & $1 \%$ & $5 \%$ & $10 \%$ \\
\hline Algeria & 0.0018 & 1.1707 & 3.7256 & 2.9732 & 2.4182 \\
\hline Benin & -0.0297 & -1.4630 & 3.5973 & 2.8560 & 2.3251 \\
\hline Cameroon & -0.0605 & $-2.6530 *$ & 3.2044 & 2.5533 & 2.0665 \\
\hline Democratic Republic of Congo & 0.0323 & .6443 & 4.2013 & 3.3794 & 2.8001 \\
\hline Egypt & 0.0130 & 3.1703 & 5.9842 & 4.8120 & 3.8893 \\
\hline Ethiopia & -0.0726 & $-4.8714 * * *$ & 4.0833 & 3.1707 & 2.5016 \\
\hline Ghana & 0.0169 & 1.5522 & 3.4621 & 2.7358 & 2.2096 \\
\hline Kenya & 0.0143 & .41122 & 4.1786 & 3.3533 & 2.7212 \\
\hline Morocco & 0.0195 & 2.5687 & 4.1563 & 3.3302 & 2.6663 \\
\hline Mozambique & -0.0042 & -.68177 & 5.5400 & 4.4874 & 3.7211 \\
\hline Nigeria & 0.0032 & .67945 & 3.3625 & 2.6768 & 2.1375 \\
\hline Senegal & -0.0119 & -1.3115 & 3.6735 & 2.9209 & 2.3153 \\
\hline South Africa & -0.0001 & -.13340 & 2.9083 & 2.3339 & 1.9136 \\
\hline Tanzania & -0.0002 & -.01174 & 3.8959 & 3.1573 & 2.5548 \\
\hline Tunisia & 0.0022 & 1.2663 & 7.5471 & 6.2518 & 5.3004 \\
\hline Zambia & 0.0005 & .08443 & 4.0273 & 3.2896 & 2.6652 \\
\hline
\end{tabular}

***. **. *: significance at the $1 \% .5 \%$ and $10 \%$ levels, respectively.

$\mathrm{H}_{0}$ : ENERGY USE does not cause EDUCATION3.

${ }^{11}$ EDUCATION3 denotes the tertiary education enrolment level. 
Table 4a - Granger causality tests from Primary Education to Electricity Consumption over the period 1971-2010, bivariate (ELECTRICITY CONSUMPTION, PRIMARY EDUCATION) model

\begin{tabular}{|c|c|c|c|c|c|}
\hline & \multirow{2}{*}{$\begin{array}{l}\text { Estimated } \\
\text { coefficient }\end{array}$} & \multirow[t]{2}{*}{ Test Statistic } & \multicolumn{3}{|c|}{ Bootstrap critical values } \\
\hline & & & $1 \%$ & $5 \%$ & $10 \%$ \\
\hline Algeria & 1.2231 & .51216 & 10.2240 & 8.8358 & 7.4743 \\
\hline Benin & 0.1759 & 2.5412 & 7.5878 & 6.2294 & 5.1436 \\
\hline Cameroon & 0.0146 & .03278 & 4.3664 & 3.4192 & 2.7040 \\
\hline Democratic Republic of Congo & 0.0432 & .33807 & 5.2312 & 4.2457 & 3.4150 \\
\hline Egypt & 0.7384 & 1.9914 & 4.7304 & 3.8345 & 3.1420 \\
\hline Ethiopia & 0.0628 & $2.2900 *$ & 2.8989 & 2.3261 & 1.8893 \\
\hline Ghana & 0.1474 & .07970 & 2.7449 & 2.1848 & 1.7271 \\
\hline Kenya & 0.2907 & $3.1101^{* * *}$ & 2.4076 & 1.9655 & 1.5919 \\
\hline Morocco & 0.7584 & 2.3942 & 6.5315 & 5.3296 & 4.3737 \\
\hline Mozambique & 0.2716 & .43508 & 5.6996 & 4.3345 & 3.3355 \\
\hline Nigeria & 1.1272 & 1.4971 & 3.7421 & 2.9578 & 2.3627 \\
\hline Senegal & 0.9886 & 5.4137 & 10.1239 & 8.5532 & 7.3659 \\
\hline South Africa & 2.2735 & $2.7309 * *$ & 2.8668 & 2.3250 & 1.8702 \\
\hline Tanzania & 0.0045 & .11107 & 3.6361 & 2.9026 & 2.3342 \\
\hline Tunisia & -0.2823 & -.36807 & 5.3438 & 4.2977 & 3.5135 \\
\hline Zambia & -1.1271 & -1.3171 & 3.6052 & 2.9154 & 2.3017 \\
\hline
\end{tabular}

***. **. *: significance at the $1 \% .5 \%$ and $10 \%$ levels, respectively.

$\mathrm{H}_{0}$ : PRIMARY EDUCATION does not cause ELECTRICITY CONSUMPTION.

Table 4b - Granger causality tests from Electricity Consumption to Primary Education over the period 1971-2010, bivariate (ELECTRICITY CONSUMPTION, PRIMARY EDUCATION) model

\begin{tabular}{lrrrrr}
\hline \hline & Estimated & Test Statistic & \multicolumn{3}{c}{ Bootstrap critical values } \\
\cline { 4 - 6 } coefficient & & & $1 \%$ & $5 \%$ & $10 \%$ \\
\hline Algeria & 0.0003 & .17313 & 2.8820 & 2.3255 & 1.8325 \\
Benin & 0.0597 & 1.2674 & 9.4907 & 7.9081 & 6.6245 \\
Cameroon & 0.0696 & $5.5149 * * *$ & 3.6165 & 2.9350 & 2.3263 \\
Democratic Republic of Congo & 0.1446 & $4.0891^{* *}$ & 4.9154 & 4.0349 & 3.3180 \\
Egypt & 0.0087 & 3.5137 & 7.8180 & 6.3039 & 5.0614 \\
Ethiopia & 0.3005 & 2.9487 & 7.6908 & 6.0492 & 4.9145 \\
Ghana & -0.0049 & -1.2901 & 4.2421 & 3.3339 & 2.6573 \\
Kenya & 0.0177 & .69237 & 7.0072 & 5.6154 & 4.5949 \\
Morocco & 0.0034 & .92042 & 4.3100 & 3.5019 & 2.8943 \\
Mozambique & 0.0167 & 2.6384 & 6.1739 & 4.9234 & 4.1009 \\
Nigeria & -0.0032 & -.47767 & 2.0509 & 1.6863 & 1.3886 \\
Senegal & 0.0195 & 1.2331 & 4.6388 & 3.6614 & 2.9397 \\
South Africa & -0.0001 & -.65462 & 2.9877 & 2.4174 & 1.9749 \\
Tanzania & 0.0646 & 1.1493 & 7.7758 & 6.4997 & 5.4545 \\
Tunisia & 0.0007 & .76708 & 8.8668 & 7.3303 & 6.2385 \\
Zambia & 0.0013 & .56628 & 4.2345 & 3.3709 & 2.7320 \\
\hline \hline
\end{tabular}

***. **. *: significance at the $1 \% .5 \%$ and $10 \%$ levels, respectively.

$\mathrm{H}_{0}$ : ELECTRICITY CONSUMPTION does not cause PRIMARY EDUCATION. 
Table 5a - Granger causality tests from Secondary Education to Electricity Consumption over the period 1971-2010, bivariate (ELECTRICITY CONSUMPTION, SECONDARY EDUCATION) model

\begin{tabular}{|c|c|c|c|c|c|}
\hline & \multirow{2}{*}{$\begin{array}{c}\text { Estimated } \\
\text { coefficient }\end{array}$} & \multirow[t]{2}{*}{ "Test Statistic } & \multicolumn{3}{|c|}{ " Bootstrap critical values } \\
\hline & & & $1 \%$ & $5 \%$ & $10 \%$ \\
\hline Algeria & 1.9991 & 2.3928 & 8.7917 & 7.5325 & 6.4044 \\
\hline Benin & 0.4717 & 3.7225 & 7.5518 & 6.2786 & 5.3170 \\
\hline Cameroon & 0.1347 & .38189 & 6.8185 & 5.6722 & 4.6325 \\
\hline Democratic Republic of Congo & -0.4938 & -1.6468 & 4.9089 & 3.9077 & 3.1262 \\
\hline Egypt & 0.0806 & .21219 & 4.6043 & 3.7381 & 3.0098 \\
\hline Ethiopia & 0.0761 & 1.2582 & 3.3562 & 2.7667 & 2.2421 \\
\hline Ghana & -0.7352 & -.56700 & 2.8569 & 2.2606 & 1.8100 \\
\hline Kenya & 0.6730 & $4.2510 * * *$ & 2.6829 & 2.1042 & 1.7439 \\
\hline Morocco & -0.3305 & -.66414 & 6.5956 & 5.3237 & 4.4190 \\
\hline Mozambique & -2.8857 & -1.7165 & 5.3496 & 4.0362 & 3.0739 \\
\hline Nigeria & 1.0560 & $3.3771^{*}$ & 4.7323 & 3.7885 & 3.0284 \\
\hline Senegal & 3.2187 & $6.5169 * * *$ & 5.9167 & 4.7128 & 3.8624 \\
\hline South Africa & -1.9610 & -.85907 & 2.9431 & 2.4362 & 1.9571 \\
\hline Tanzania & 2.8748 & 2.9584 & 6.8998 & 5.6155 & 4.5432 \\
\hline Tunisia & 0.6751 & 1.0465 & 9.4165 & 7.8975 & 6.7522 \\
\hline Zambia & -19.5350 & $-4.6631 *$ & 6.5010 & 5.3623 & 4.4493 \\
\hline
\end{tabular}

***. **. *: significance at the $1 \% .5 \%$ and $10 \%$ levels, respectively.

$\mathrm{H}_{0}$ : SECONDARY EDUCATION does not cause ELECTRICITY CONSUMPTION.

Table 5b - Granger causality tests from Electric Electricity Consumption to Secondary Education over the period 1971-2010, bivariate (ELECTRICITY CONSUMPTION, SECONDARY EDUCATION) model

\begin{tabular}{lrrrrr}
\hline \hline & Estimated & Test Statistic & \multicolumn{3}{c}{ Bootstrap critical values } \\
\cline { 5 - 6 } coefficient & & & \multicolumn{1}{c}{$1 \%$} & \multicolumn{1}{c}{$5 \%$} & \multicolumn{1}{c}{$10 \%$} \\
\hline Algeria & 0.0347 & $4.9642 *$ & 9.9184 & 8.4657 & 2.2875 \\
Benin & 0.0094 & .36129 & 7.6755 & 6.2978 & 5.1356 \\
Cameroon & 0.0432 & $5.7629 * * *$ & 4.5603 & 3.6631 & 2.9185 \\
Democratic Republic of Congo & -0.0001 & -.8672 & 3.3935 & 2.6804 & 2.1030 \\
Egypt & -0.0057 & -1.9855 & 3.6781 & 2.9641 & 2.4040 \\
Ethiopia & 0.1500 & 1.9195 & 8.9030 & 7.3449 & 6.1275 \\
Ghana & -0.0049 & -1.6372 & 3.1939 & 2.5392 & 1.9950 \\
Kenya & 0.0656 & 1.3571 & 7.1490 & 5.8148 & 4.8120 \\
Morocco & 0.0081 & 3.0705 & 9.8926 & 8.4250 & 7.2772 \\
Mozambique & 0.0076 & $6.8377 * * *$ & 4.5173 & 3.6040 & 2.8749 \\
Nigeria & 0.0140 & .85550 & 6.5825 & 5.3797 & 4.5045 \\
Senegal & 0.0318 & 2.7567 & 4.6682 & 3.8472 & 3.1388 \\
South Africa & 0.0008 & 1.3662 & 5.8961 & 4.8714 & 3.9739 \\
Tanzania & 0.1815 & 2.4149 & 12.4671 & 11.0144 & 9.8007 \\
Tunisia & 0.0131 & 3.2536 & 14.1648 & 12.6872 & 11.4336 \\
Zambia & -0.0002 & -.28421 & 6.6152 & 5.4952 & 4.6629 \\
\hline \hline
\end{tabular}

***. **. *: significance at the $1 \% .5 \%$ and $10 \%$ levels, respectively.

$\mathrm{H}_{0}$ : ELECTRICITY CONSUMPTION does not cause SECONDARY EDUCATION. 
Table 6a - Granger causality tests from Tertiary Education to Electricity Consumption over the period 1971-2010, bivariate (ELECTRICITY CONSUMPTION, TERTIARY EDUCATION) model

\begin{tabular}{|c|c|c|c|c|c|}
\hline & \multirow{2}{*}{$\begin{array}{c}\text { Estimated } \\
\text { coefficient }\end{array}$} & \multirow[t]{2}{*}{ Test Statistic } & \multicolumn{3}{|c|}{ Bootstrap critical values } \\
\hline & & & $1 \%$ & $5 \%$ & $10 \%$ \\
\hline Algeria & 5.2781 & $3.7914 * * *$ & 3.4358 & 2.7672 & 2.2105 \\
\hline Benin & 0.6928 & 1.3047 & 7.6014 & 6.2908 & 5.2886 \\
\hline Cameroon & 3.3006 & 2.4561 & 5.2109 & 4.1002 & 3.3004 \\
\hline Democratic Republic of Congo & -1.4076 & -1.2191 & 3.8656 & 3.1199 & 2.5399 \\
\hline Egypt & 0.8694 & 1.4739 & 4.2961 & 3.4333 & 2.8107 \\
\hline Ethiopia & 2.6332 & $7.3795^{* * *}$ & 3.3119 & 2.6114 & 2.1113 \\
\hline Ghana & -1.3999 & -.35043 & 2.9530 & 2.3746 & 1.9387 \\
\hline Kenya & 3.9556 & $5.0887 * * *$ & 2.8410 & 2.3090 & 1.8869 \\
\hline Morocco & -0.0870 & -.08787 & 5.0640 & 4.0636 & 3.2137 \\
\hline Mozambique & -7.4608 & -.83862 & 3.0834 & 2.3281 & 1.8329 \\
\hline Nigeria & 4.8520 & $5.6952 * * *$ & 3.9685 & 3.2088 & 2.5131 \\
\hline Senegal & 8.6888 & $5.1757 * *$ & 5.2276 & 4.1451 & 3.3843 \\
\hline South Africa & 0.6003 & .10657 & 3.5377 & 2.8082 & 2.2543 \\
\hline Tanzania & 7.8035 & $3.0124^{*}$ & 3.9686 & 3.1865 & 2.5931 \\
\hline Tunisia & 1.1719 & 1.2997 & 7.2590 & 5.8287 & 4.7529 \\
\hline Zambia & -27.4018 & -1.2479 & 6.0098 & 4.8669 & 4.0878 \\
\hline
\end{tabular}

***. **. *: significance at the $1 \% .5 \%$ and $10 \%$ levels, respectively.

$\mathrm{H}_{0}$ : TERTIARY EDUCATION does not cause ELECTRICITY CONSUMPTION.

Table 6b - Granger causality tests from Electric Electricity Consumption to Tertiary Education over the period 1971-2010, bivariate (ELECTRICITY CONSUMPTION, TERTIARY EDUCATION) model

\begin{tabular}{lrrrrr}
\hline \hline & Estimated & Test Statistic & \multicolumn{3}{c}{ Bootstrap critical values } \\
\cline { 4 - 6 } coefficient & & & $1 \%$ & $5 \%$ & $10 \%$ \\
\hline Algeria & 0.0022 & $3.0094^{*}$ & 5.9812 & 4.7499 & 2.7990 \\
Benin & 0.0393 & 5.6641 & 12.7436 & 11.1395 & 9.8078 \\
Cameroon & 0.0031 & $2.4544 *$ & 4.0068 & 3.2055 & 2.1263 \\
Democratic Republic of Congo & -0.0029 & -1.1755 & 7.0347 & 5.8918 & 4.9018 \\
Egypt & 0.0029 & 1.9937 & 6.1298 & 4.5662 & 3.5136 \\
Ethiopia & 0.0000 & .23257 & 3.9480 & 3.2309 & 2.6235 \\
Ghana & -0.0010 & -.72338 & 3.7391 & 2.9534 & 2.3440 \\
Kenya & 0.0034 & 1.2845 & 6.7003 & 5.6552 & 4.9119 \\
Morocco & 0.0009 & .77141 & 3.3926 & 2.7010 & 2.2430 \\
Mozambique & 0.0015 & $4.9440 *$ & 6.8238 & 5.1330 & 4.0659 \\
Nigeria & 0.0121 & 2.2432 & 6.8545 & 5.5057 & 4.6253 \\
Senegal & 0.0181 & $5.3215 *$ & 6.9900 & 5.6982 & 4.6650 \\
South Africa & 0.0005 & 1.7325 & 6.9399 & 5.9327 & 4.9095 \\
Tanzania & 0.0010 & .59121 & 3.4159 & 2.7740 & 2.2859 \\
Tunisia & 0.0030 & $4.5093 *$ & 9.4282 & 7.9480 & 3.9181 \\
Zambia & -0.0008 & $-3.1658 * * *$ & 2.6182 & 2.1418 & 1.7949 \\
\hline \hline
\end{tabular}

***. **. *: significance at the $1 \% .5 \%$ and $10 \%$ levels, respectively.

$\mathrm{H}_{0}$ : ELECTRICITY CONSUMPTION does not cause TERTIARY EDUCATION. 


\section{DAVIDSON INSTITUTE WORKING PAPER SERIES - Most Recent Papers}

The entire Working Paper Series may be downloaded free of charge at: www.wdi.umich.edu

CURRENT AS OF 9/26/14

\begin{tabular}{|c|c|c|}
\hline Publication & Authors & Date \\
\hline $\begin{array}{l}\text { No. 1084: Testing the causality between electricity consumption, energy } \\
\text { use and education in Africa }\end{array}$ & $\begin{array}{c}\text { Oussama BEN ABDELKARIM, } \\
\text { Adel BEN YOUSSEF, } \\
\text { Hatem M'HENNI and } \\
\text { Christophe RAULT } \\
\end{array}$ & Sept 2014 \\
\hline $\begin{array}{l}\text { No. 1083: Measuring and analyzing the non-monetary approach of } \\
\text { multidimensional poverty by the basic needs in Togo }\end{array}$ & Yawo Agbényégan NOGLO & Aug 2014 \\
\hline $\begin{array}{l}\text { No. 1082: Liquidity Constraints, Loss Aversion, and Myopia: Evidence } \\
\text { from Central and Eastern European Countries }\end{array}$ & Ramiz Rahmanov & Aug 2014 \\
\hline $\begin{array}{l}\text { No. 1081: The Real Exchange Rate and Growth in Zimbabwe: Does the } \\
\text { Currency Regime Matter? }\end{array}$ & $\begin{array}{l}\text { Zuzana Brixiová and Mthuli } \\
\text { Ncube }\end{array}$ & Aug 2014 \\
\hline $\begin{array}{l}\text { No. 1080: Recent Estimates of Exchange Rate Pass-Through to } \\
\text { Import Prices in the Euro Area }\end{array}$ & $\begin{array}{l}\text { Nidhaleddine Ben Cheikh and } \\
\text { Christophe Rault }\end{array}$ & Aug 2014 \\
\hline No. 1079: How smooth is the stock market integration of CEE-3? & $\begin{array}{l}\text { Eduard Baumöhl and } \\
\text { Štefan Lyócsa }\end{array}$ & June 2014 \\
\hline $\begin{array}{l}\text { No. 1078: The Role of the Business Cycle in Exchange } \\
\text { Rate Pass-Through: The Case of Finland }\end{array}$ & $\begin{array}{l}\text { Nidhaleddine Ben Cheikh and } \\
\text { Christophe Rault }\end{array}$ & June 2014 \\
\hline $\begin{array}{l}\text { No. 1077: Skills and youth entrepreneurship in Africa: Analysis with } \\
\text { evidence from Swaziland }\end{array}$ & $\begin{array}{l}\text { Zuzana Brixiova, Mthuli Ncube \& } \\
\text { Zorobabel Bicaba }\end{array}$ & May 2014 \\
\hline $\begin{array}{l}\text { No. 1076: Can Dreams Come True? Eliminating Extreme Poverty In } \\
\text { Africa By } 2030\end{array}$ & $\begin{array}{l}\text { Mthuli Ncube, Zuzana Brixiova } \\
\text { \& Zorobabel Bicaba }\end{array}$ & April 2014 \\
\hline $\begin{array}{l}\text { No. 1074: Bridging the Gender Gap in Entrepreneurship: Evidence from } \\
\text { Europe }\end{array}$ & Elvin Afandi \& Majid Kermani & Feb 2014 \\
\hline $\begin{array}{l}\text { No. 1073: Can Intra-Regional Trade Act as a Global Shock Absorber } \\
\text { in Africa? }\end{array}$ & $\begin{array}{l}\text { Mthuli Ncube, Zuzana Brixiova } \\
\text { \& Qingwei Meng }\end{array}$ & Feb 2014 \\
\hline No. 1072: The Dynamics of Firm Lobbying & $\begin{array}{l}\text { William R. Kerr, William F. } \\
\text { Lincoln and Prachi Mishra }\end{array}$ & Jan 2014 \\
\hline $\begin{array}{l}\text { No. 1071: Skilled Immigration and the Employment Structures of U.S. } \\
\text { Firms }\end{array}$ & $\begin{array}{l}\text { Sari Pekkala Kerr, William R. } \\
\text { Kerr and William F. Lincoln }\end{array}$ & Jan 2014 \\
\hline $\begin{array}{l}\text { No. 1070: Exchange Rate Pass-Through to Domestic Prices } \\
\text { under Different Exchange Rate Regimes }\end{array}$ & Rajmund Mirdala & Jan 2014 \\
\hline $\begin{array}{l}\text { No. 1069: Ailing Mothers, Healthy Daughters? Contagion } \\
\text { in the Central European Banking Sector }\end{array}$ & Tomas Fiala \& Tomas Havranek & Jan 2014 \\
\hline $\begin{array}{l}\text { No. 1068: The Real Exchange Rate and External Competitiveness in Egypt, } \\
\text { Morocco and Tunisia }\end{array}$ & $\begin{array}{l}\text { Zuzana Brixiova, Balázs Égert, } \\
\text { and Thouraya Hadj Amor Essid }\end{array}$ & Jan 2014 \\
\hline $\begin{array}{l}\text { No. 1067: Economic (In)Security And Gender Differences In Trade Policy } \\
\text { Attitudes }\end{array}$ & $\begin{array}{l}\text { Jeffrey Drope and } \\
\text { Abdur Chowdhury }\end{array}$ & Jan 2014 \\
\hline $\begin{array}{l}\text { No. 1066: Do business groups help or hinder technological progress in } \\
\text { emerging markets? Evidence from India }\end{array}$ & $\begin{array}{l}\text { Sumon K. Bhaumik and } \\
\text { Ying Zhou }\end{array}$ & Jan 2014 \\
\hline $\begin{array}{l}\text { No. 1065: Fiscal Imbalances and Current Account Adjustments } \\
\text { in the European Transition Economies }\end{array}$ & Rajmund Mirdala & Nov 2013 \\
\hline
\end{tabular}

